\title{
SIGNIFICANCE OF PELLETING THE SEED WITH PHOSPHATE AND LIME ON THE CULTIVATION OF SOYBEAN IN ACID SOILS IN SITIUNG, WEST SUMATRA
}

\author{
Setiyo Hadi Waluyo \\ Agriculture Division, Center for the Application of Isotopes and Radiation Technology, \\ National Nuclear Energy Agency, Jakarta, Indonesia \\ Jln. Cinere Pasar Jumat, Kotak Pos 7002, JKSKL, Jakarta, 12070 \\ Phone : + 6221 7690709/08121106683. Fax. : +62 21 7513270; E-mail : shwaluyo@yahoo.com
}

\begin{abstract}
Several experiments containing 2 field, 2 pot and 1 rhizotron were conducted to develop a low input agricultural practice (pelleting seed) for production of soybean plant (cv. Tidar) on heavily acid soils of Sitiung, West Sumatra. The field and pot experiments were conducted in Sitiung and in the greenhouse at the Agriculture Division. Center for the Application of Isotopes and Radiation Technology, National Nuclear Energy Agency, Jakarta, respectively, in 1990 - 1992. The rhizotron experiment was conducted in 1994 at the Laboratory of Microbiology, Department of Agrotechnology and Food Sciences, Wageningen University, Wageningen, The Netherlands. Lime-pelleting seeds with the equivalent of $50 \mathrm{~kg}$ lime ha' increased nodulation, growth and yield both in unlimed and limed soils. Considerable increases in nodulatio, growth and yield were

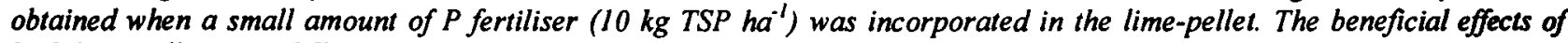
both lime-pelleting and [lime +TSP]-pelleting were more pronounced on nodulation than on growth and yield, and greater in unlimed soils than in limed soils. Large effects were obtained in nodulation, growth and yield of soybean in field experiments by pelleting seeds with lime or with lime +TSP. However, the pelleted soybean plants grown in unlimed soils remained small and yields were negligible. To sustain growth and production of soybean in these acid soils, adequate quantities of lime and of $P$ fertiliser would be necessary. In the present study, a combination of broadcast lime at 2.0 t hat with [lime+TSP]-pelleting of inoculated seeds was found superior to the application of $7.0 \mathrm{tha}$ h of lime with inoculated seeds only. Al toxicity and $P$ deficiency were the main problems in these acid soils. For the low-input production of soybeans considerations should be directed to the correction of these factors.
\end{abstract}

Keywords: Acid soils, seed pelleting, soybean, nodulation, yield

\section{INTRODUCTION}

Sitiung is one of the new agricultural areas opened up for new settlement (transmigration) in West Sumatra, Indonesia. The area has infertile acid soils $(\mathrm{pH}=4.03)$, and is populated by poor farmers. Recently, more attention has been given to the Sitiung areas for the national Indonesian program of attaining self-sufficiency in soybean (Sudjadi, 1984; Wade et al., 1988).

Exploration of soybean BNF has the potential for considerable improvement in yield, and for the development of sustainable agriculture. This is particularly important in areas with economic constraints and where low-input management is practised. However, BNF and growth of soybean on weathered acid soils is limited by acidity and related factors such as $\mathrm{Al}$ toxicity, $\mathrm{Ca}, \mathrm{P}$ and some micro-nutrient deficiencies (Munns, 1977; Alva et al., 1987; Coventry and Evans, 1989).

Liming and $P$ fertilization increase soybean yield and BNF on acid soils (Sartain and Kamprath, 1975; Abruna, 1979). Those techniques are costly and cannot be afforded by the poor local farmers. Therefore, low-input technologies need to be developed in an attempt to encourage local farmers to increase soybean production. Lime-pelleting seeds have been successfully dẹveloped to improve BNF and the establishment of some temperate legumes in acid soils in Australia (Mannetje, 1967; Diatloff and Luck, 1972). However, this technique is considered less effective on heavily weathered acid soils (Cregan et al., 1989).

Soybean is a plant with high-P requirement, whereas $P$ is deficient in heavily weathered acid soils. In the present study, [lime-TSP]-pelleting of soybean seed, and lime application on soils from the Sitiung area, were investigated.

\section{MATERIALS AND METHODS}

This paper reports the results of field, pot, and rhizotron experiments. Two field experiments were conducted in Sitiung in 1990 and 1992 and two pot experiments in 1990 and 1991 in the greenhouse at CAIRNAEA (Centre for the Application of Isotopes and Radiation Technology, National Nuclear Energy Agency), Jakarta.

Rhizotron experiment was conducted in 1994 at the Department of Microbiology, Wageningen University. The pot and rhizotron experiments were performed to study the treatments used in the field experiments at laboratory scale. Rhizotron experiment allows a more detailed study of various aspects of BNF. 


\section{Field Experiments}

The chemical properties of the soils in Sitiung are shown in Table 1 . Urea ( $25 \mathrm{~kg} \mathrm{~N} \mathrm{ha}^{-1}$ ), TSP (100 kg TSP $\left.\mathrm{ha}^{-1}\right)$, and $\mathrm{KCl}\left(100 \mathrm{~kg} \mathrm{KCl} \mathrm{ha}{ }^{-1}\right)$ were applied as basic nutrients. Lime requirement (LR) for maximum growth of soybean plants was calculated as 6.75 tons lime per hectare, using the formula of Wade et al. (1988):

\section{$L R=1.5 /\{A l-(R A S \times E C E C / 100)\}\}$}

where:

$\mathrm{Al}=$ exchangeable aluminium; RAS= percentage of aluminium saturation; $E C E C=$ effective cation exchange capacity].

Table 1. Properties of the Sitiung Soils

\begin{tabular}{lc}
\hline \multicolumn{1}{c}{ Characteristics } & Value \\
\hline Clay (\%) & $74.5^{*}$ \\
Organic C (\%) & $2.0^{*}$ \\
Available P (ppm) & $<5.0^{*}$ \\
$\mathrm{pH}\left(\mathrm{H}_{2} \mathrm{O}\right)$ & 4.03 \\
$\mathrm{pH}(\mathrm{KCl})$ & 3.65 \\
Cations (cmol kg-1 soil) & \\
$\mathrm{Ca}$ & 0.4 \\
$\mathrm{Mg}$ & 0.2 \\
$\mathrm{~K}$ & 0.14 \\
$\mathrm{Al}+\mathrm{H}$ & 6.32 \\
$\mathrm{Al}$ & 5.56 \\
$\mathrm{Na}$ & 0.4 \\
$\mathrm{Al}$ saturation (\%) & 88 \\
\hline
\end{tabular}

- Adapted from Sudjadi (1984).

The amount of lime used for pelleting soybean seeds was equivalent to $50 \mathrm{~kg} \mathrm{ha}^{-1}$. The lime used in this experiment, was agricultural lime (Kapur pertanian in
Indonesian). Soybean seed of the cv. Tidar was sown at the rate of $50 \mathrm{~kg} \mathrm{ha}^{-1}$. The seeds for each treatment were treated with an appropriate Bradyrhizobium inoculant. The treated seeds were planted in holes with a depth of $5 \mathrm{~cm} \mathrm{(3}$ seeds hole ${ }^{-1}$ ) on a grid of $0.30 \times 0.20 \mathrm{~m}^{2}$. Plot size was $3.0 \mathrm{x}$ $4.0 \mathrm{~m}^{2}$. The total numbers of plots were 48 and the total area was $576 \mathrm{~m}^{2}$. The treatments were applied in an incomplete factorial with 6 replications (Table 2).

Field experiment II was similar to field experiment I, except that the coating material for the seed pellets was a mixture of TSP $\left(10 \mathrm{~kg} \mathrm{ha}^{-1}\right)$ with lime $\left(50 \mathrm{~kg} \mathrm{ha}^{-1}\right)$. Planting distance was $0.2 \times 0.15 \mathrm{~m}^{2}$. There were 48 plots of $3.9 \times 3$ $\mathrm{m}^{2}$ in a total area of $561.8 \mathrm{~m}^{2}$. The treatments were applied in an incomplete factorial with 4 replications (Table 2).

\section{Pot Experiments}

Pot experiment I was an imitation of field experiment I without $\mathrm{N}$ treaments. Soil was collected from the area of field experiment 1 . LR was calculated by assuming that the mass of 1.0 ha of top-soil equal to $2 \times 10^{6} \mathrm{~kg}$. Air-dried soil was ground and screened by a $0.5 \mathrm{~cm}$ sieve. Plastic pots (diam.: $25 \mathrm{~cm}$ and height: $30 \mathrm{~cm}$ ) were filled with $2.5 \mathrm{~kg}$ of air-dried soil. Soybean seeds were sown in a hole ( 2 seeds hole $\left.^{-1}\right)$. There were 3 holes pot $^{-1}$. The plants were thinned to 2 plants pot $^{-1}$ after emergence. Tap water was added to bring the soils approximately to field capacity. This moisture level was maintained throughout the experiment by regularly weighing and watering the pots. The soybean plants were harvested at the stage of $50 \%$ flowering. Materials and methods for pot experiment II were similar to those of pot experiment I, except that TSP-pellet and [Lime+TSP]-pellet treatments were included.

\section{Rhizotron Experiment}

A thizotron was made from a plastic-petri dish $9.0 \mathrm{~cm}$ in diameter, cut of the top of $0.5 \mathrm{~cm}$ to allow the soybean plant to grow outside the rhizotron (Fig. 1).

Table 2. Treatments Used in Fields Experiments

\begin{tabular}{|c|c|c|c|c|c|c|c|c|}
\hline \multicolumn{4}{|c|}{ Experiment I } & \multicolumn{5}{|c|}{ Experiment II } \\
\hline \multirow{2}{*}{$\begin{array}{l}\text { Lime } \\
\left(\mathrm{t} \mathrm{ha}^{-1}\right)\end{array}$} & \multicolumn{3}{|c|}{ Inoculation } & \multirow{2}{*}{$\begin{array}{l}\text { Lime } \\
\left(\mathrm{t} \mathrm{ha} \mathrm{a}^{-1}\right)\end{array}$} & \multirow[b]{2}{*}{ Control } & \multicolumn{3}{|c|}{ Inoculation } \\
\hline & Legin & $\begin{array}{c}\text { Legint } \\
\text { Ca-pellet }\end{array}$ & $\begin{array}{c}\text { Nitrogen } \\
\left(100 \mathrm{~kg} \mathrm{~N} \mathrm{ha}{ }^{-1}\right)\end{array}$ & & & Legin & $\begin{array}{c}\text { Legint } \\
\text { Ca-pellet }\end{array}$ & $\begin{array}{c}\text { Legint } \\
\text { CaP-pelle }\end{array}$ \\
\hline \multirow[t]{2}{*}{0} & + & + & + & 0 & + & - & + & + \\
\hline & & & & 2.0 & - & + & + & + \\
\hline 3.5 & + & + & + & 3.5 & + & + & + & + \\
\hline 7.0 & + & - & + & 7.0 & + & + & - & - \\
\hline
\end{tabular}

Note: $(+)$ indicates presence and (-)indicates absence of treatment 

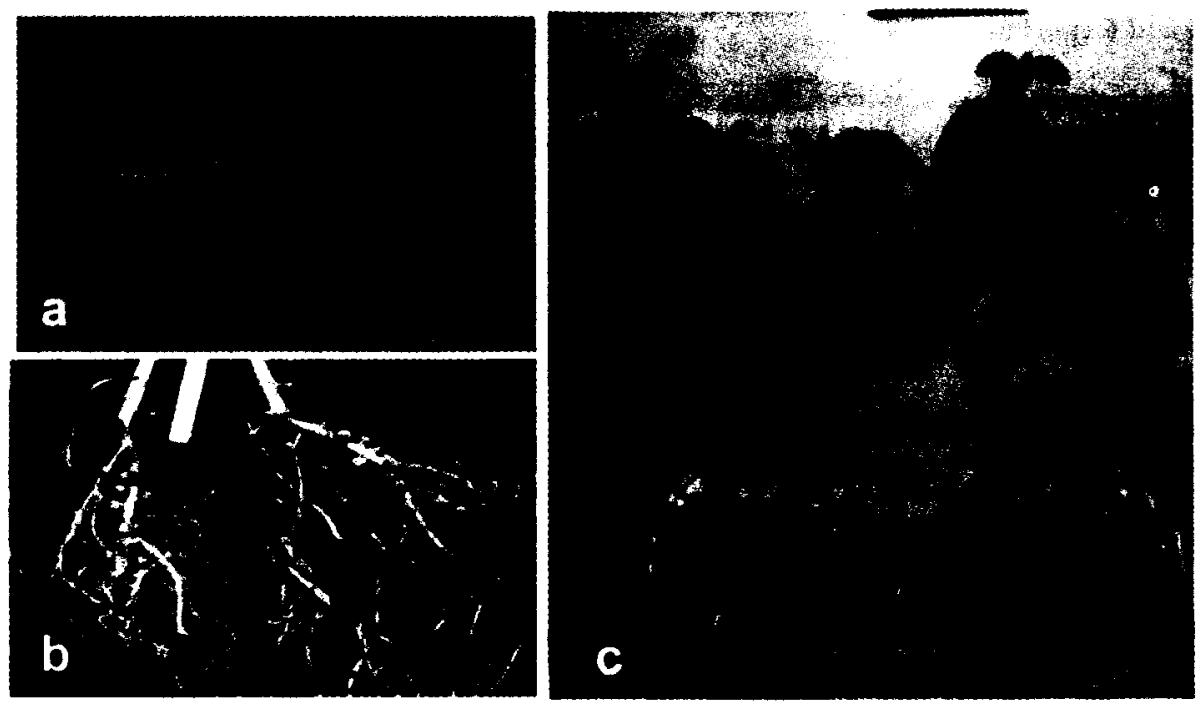

Figure 1. a) A Rhizotron; Empty (Left), Filled with Soil (Right), the Lid (Bottom); b) Harvested Roots, c) Rhizotron with Soybean Plants.

The rhizotron experiment was carried out to investigate the effects of lime and [lime+TSP] pelleting soybean seed on nodulation, growth and development of roots of soybean in acid soils. The air-dried soil was moistened to field capacity before being put into the rhizotrons $\left(70 \mathrm{~g}\right.$ rhizotron $\left.{ }^{-1}\right)$. In this experiment, all treatments, lime-pellet, [lime+TSP]-pellet and Bradyrhizobium inoculant (broth) were applied directly to $0.5 \mathrm{~cm}$ below the root tips. As pelleting material $\mathrm{CaCO}_{3}$ was used and firstly dissolved in sterile water $(0.075 \mathrm{~g} 0.5$ $\mathrm{ml}^{-1}$ seedling ${ }^{-1}$, equivalent to $50 \mathrm{~kg}$ lime $\left.\mathrm{ha}^{-1}\right)$. For [lime+TSP]-pellet treatments, besides lime, $0.5 \mathrm{ml}$ of a solution containing $0.0125 \mathrm{~g}$ TSP seedling (equivalent to $10 \mathrm{~kg}$ TSP ha) were applied. Soybean seeds were sterilised by immersing them sequentially in ethanol $70 \%$ for 10 minutes, then in $6 \%$ of hydrogen peroxide containing 1 drop of Tween 20 for 10 minutes. The sterile soybean seeds were rinsed with sterile water at least 3 times. They were then germinated on water-agar $0.7 \%$ for $24-48$ hours. Seedlings were transplanted into the rhizotrons and incubated for 24 hours.

The plants were harvested 20 days after treatments were applied. Number and fresh weight of nodules were determined.

\section{RESULTS AND DISCUSSION}

Growth, nodulation and yield of soybean plants grown in Sitiung were increased by lime (Table 3). The beneficial effects of Bradyrhizobium japonicum inoculation were intensified significantly by coating the inoculated soybean seeds with a small amount of lime $\left(50 \mathrm{~kg} \mathrm{ha}^{-1}\right)$, which increased BNF and growth both in field and pot experiments (Fig. 2; Table 3 and Table 4). Similar results were found in the rhizotron experiment (Tables 5). The enhancement of nodulation was pronounced by incorporating a small amount of P $\left(10 \mathrm{~kg} \mathrm{TSP} \mathrm{ha}^{-1}\right)$ to the lime-pellet (Table 3 and Table 4). In field experiments, on soils, which received $2.0 \mathrm{t} \mathrm{ha}^{-1}$ of lime, the number of nodules obtained from inoculated soybean seeds pelleted with lime+TSP was almost twice that obtained from inoculated seed only.

In pot experiment II (Table 4), however, the effects were stronger for number and weight of nodules than for the growth of soybean. Compared to that was seed inoculated only, the number of nodules obtained from inoculated seeds treated with [lime+TSP]-pellet was increased 4 times on soils limed with of $3.5 \mathrm{t} \mathrm{ha}^{-1}$. Nodule weight was increased 10 times. In the rhizotron experiment, number of nodules obtained from [lime+TSP]-pellet was greater than from lime-pelleting alone (Table 5). Visual observations showed that the rate of nodule development and leghaemoglobin content of nodules were increased by $\mathbf{P}$ supply. Nodules in the [lime+TSP] treatment were more effective, big and red, than those from lime only.

A similar pattern was found in total $\mathrm{N}$ and the dry matter yield (Table 3 ). In the field experiments I, liming with 3.5 and $7.0 \mathrm{t} \mathrm{ha}^{-1}$ more than doubled the dry matter production of shoots. Total $\mathrm{N}$ yield of shoots was also increased more than twofold by lime. Liming with 3.5 tons of lime ha ${ }^{-1}$ (broadcast) and pelleting the seeds with $50 \mathrm{~kg}$ of lime ha ${ }^{-1}$ produced higher $\mathrm{N}$ total of shoots than liming the soils with $7.0 \mathrm{t} \mathrm{ha}^{-1}$. Compared to the control treatment, there was an extra $574 \mathrm{mg} \mathrm{N}$ uptake by the plants growing on the limed soils. Total $\mathrm{N}$ yield obtained from the application of lime at $3.5 \mathrm{t} \mathrm{ha}^{-1}$ together with $50 \mathrm{~kg}$ of lime $\mathrm{ha}^{-1}$ in a seed-pellet yielded around $45 \%$ of that obtained from the soils receiving lime at $7.0 \mathrm{t} \mathrm{ha}^{-1}$ and urea at $100 \mathrm{~kg}$ $\mathrm{ha}^{-1}$.

The pot experiments confirmed these results (Table 4). However, there were differences between the results from field and pot experiments. The effect of lime on soybean growth was greater in the field than in pot experiments. The differences can probably be explained because plants in the field have a larger volume of soil to grow in. 

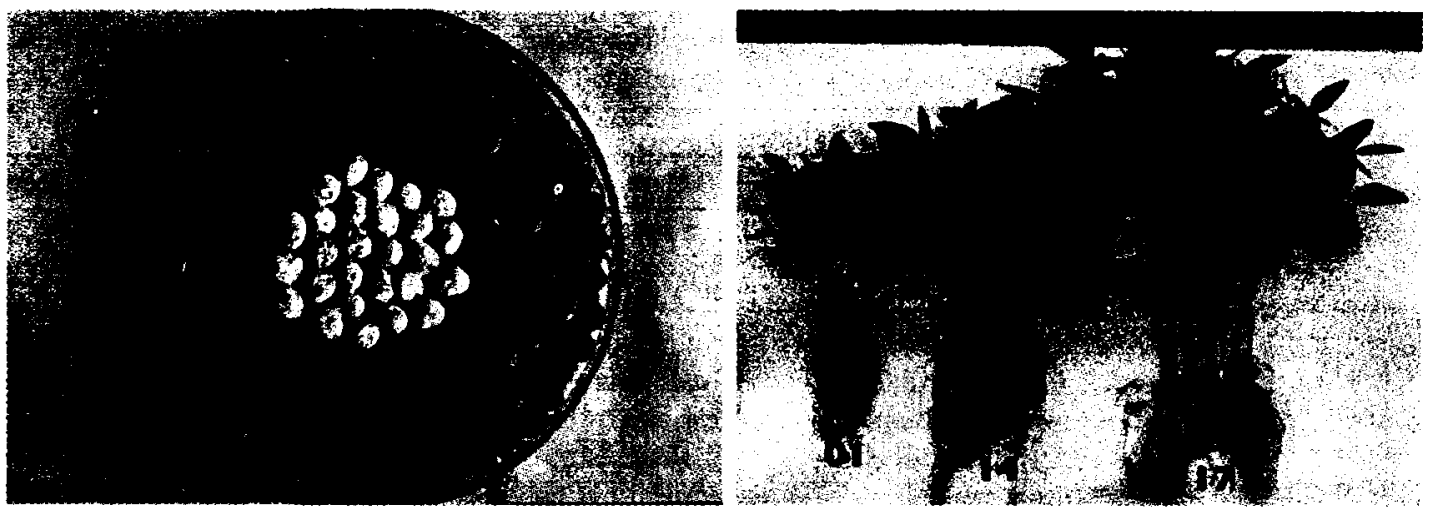

Figure 2. Left: Soybean Seeds (yellow); Inoculated Seeds ( Black) and Inoculated + Pelleted Seeds (White). Below : Growth and Nodulation of Soybean (Glycine max cv. Tidar) Harvested from a Field Experiment at Sitiung; $01=$ Control (only $5 \%$ plant grew on this plot), $14=$ Rhizobium + Lime-pellet $\left(50 \mathrm{~kg}\right.$ lime ha $\left.{ }^{-1}\right), 17=$ Lime $\left(3.5 \mathrm{tha}^{-\mathrm{l}}\right)+$ Rhizobium + Lime-pellet (50 kg lime ha $\left.{ }^{-1}\right)$.

Table 3. Growth and Nodulation of Soybean cv.Tidar at Sitiung with Different Treatments of Lime and Lime-Pelleting (Field Experiment)

\begin{tabular}{|c|c|c|c|c|c|c|c|c|c|c|c|c|c|}
\hline \multirow{3}{*}{$\begin{array}{l}\text { Lime } \\
\left(\mathrm{t} \mathrm{ha}^{-1}\right)\end{array}$} & \multirow{3}{*}{ Inoculation } & \multicolumn{4}{|c|}{ Experiment I } & \multicolumn{8}{|c|}{ Experiment II } \\
\hline & & \multicolumn{2}{|c|}{$\begin{array}{l}\text { Nodulation } \\
\text { plants }^{-1}\end{array}$} & \multicolumn{2}{|c|}{ Shoots plants ${ }^{-1}$} & \multicolumn{2}{|c|}{$\begin{array}{l}\text { Nodulation } \\
\text { plants }^{-1}\end{array}$} & \multicolumn{2}{|c|}{ Shoots plants ${ }^{-1}$} & \multicolumn{2}{|c|}{$\begin{array}{l}\text { Yield } \\
\left(\mathrm{kg} \mathrm{ha}^{-1}\right)\end{array}$} & \multicolumn{2}{|c|}{$\begin{array}{l}\text { P Uptake } \\
\left(\mathrm{kg} \mathrm{ha}^{-1}\right) \\
\text { (mg plants }\end{array}$} \\
\hline & & Number & $\begin{array}{l}\text { Dry } \\
\text { Weight } \\
\text { (mg) }\end{array}$ & $\begin{array}{l}\text { Dry } \\
\text { Weight } \\
\text { (g) }\end{array}$ & $\begin{array}{l}\mathrm{N} \text { total } \\
(\mathrm{mg})\end{array}$ & Number & $\begin{array}{l}\text { Dry } \\
\text { Weight } \\
\text { (mg) }\end{array}$ & $\begin{array}{l}\text { Dry } \\
\text { Weight } \\
\text { (g) }\end{array}$ & $\begin{array}{l}\mathrm{N} \text { total } \\
(\mathrm{mg})\end{array}$ & Grain & $\mathrm{P}^{* *}$ & & \\
\hline \multirow{5}{*}{0} & $\begin{array}{l}\text { Control (no } \\
\text { inoculation) }\end{array}$ & - & - & - & - & $0 \mathrm{e}$ & $0.0 \mathrm{e}$ & $0.7 \mathrm{~d}$ & $14.4 \mathrm{e}$ & $87 e$ & 0.6 & 0.21 & 0 \\
\hline & Legin & $9 \mathrm{e}$ & $23.0 \mathrm{bc}$ & $1.2 \mathrm{~cd}$ & 32.5 & - & - & - & - & - & - & - & - \\
\hline & Nitrogen & of & $7.0 \mathrm{c}$ & $2.4 \mathrm{bc}$ & 62.3 & - & - & - & - & - & - & - & - \\
\hline & $\begin{array}{l}\text { Legin + Lime- } \\
\text { pellet }\end{array}$ & $17 \mathrm{bc}$ & $43.0 \mathrm{ab}$ & $1.6 \mathrm{bcd}$ & 46.9 & $15 \mathrm{bcd}$ & $51.1 \mathrm{de}$ & $0.8 \mathrm{~cd}$ & $21.1 \mathrm{de}$ & $75 \mathrm{e}$ & 0.5 & 0.12 & 0.7 \\
\hline & $\begin{array}{l}\text { Legin }+ \\
{[\text { Lime+TSP]-pellet }}\end{array}$ & - & - & - & - & $21 a b$ & $79.4 \mathrm{bcd}$ & $1.1 \mathrm{bcd}$ & $27.8 \mathrm{cde}$ & $319 \mathrm{cde}$ & 1.9 & 0.16 & 1.3 \\
\hline \multirow{3}{*}{$\begin{array}{c}2.0 \\
\text { (Broadcast } \\
\text { and } \\
\text { Mixed) }\end{array}$} & Legin & - & - & - & - & $13 \mathrm{~cd}$ & $75.6 \mathrm{~cd}$ & $1.8 \mathrm{abc}$ & 52.8abcd & $471 \mathrm{bcd}$ & 2.8 & 2.45 & 3.8 \\
\hline & $\begin{array}{l}\text { Legin + Lime- } \\
\text { pellet }\end{array}$ & - & - & - & - & $18 \mathrm{abcd}$ & $74.4 \mathrm{~cd}$ & $1.6 \mathrm{abcd}$ & 48.9abcde & $498 \mathrm{bcd}$ & 2.7 & 2.29 & 3.4 \\
\hline & $\begin{array}{l}\text { Legin }+ \\
\text { [Lime+TSP]-pellet }\end{array}$ & - & - & - & - & $23 a$ & $111.7 \mathrm{a}$ & $2.3 \mathrm{a}$ & $76.7 \mathrm{a}$ & $870 a$ & 5.0 & 3.32 & 6.2 \\
\hline \multirow{5}{*}{$\begin{array}{c}3.5 \\
\text { (Broadcast } \\
\text { and } \\
\text { Mixed) }\end{array}$} & $\begin{array}{l}\text { Control (no } \\
\text { inoculation) }\end{array}$ & - & - & - & - & le & $11.7 \mathrm{e}$ & $1.9 \mathrm{ab}$ & $57.8 \mathrm{abc}$ & $213 \mathrm{de}$ & 1.1 & 0.79 & 4.3 \\
\hline & Legin & $12 a b$ & $44.0 \mathrm{ab}$ & $2.7 \mathrm{~b}$ & 71.0 & $19 a b c$ & 96.1abc & $2.1 \mathrm{ab}$ & $72.2 \mathrm{a}$ & $328 \mathrm{cde}$ & 2.0 & 1.65 & 5.8 \\
\hline & Nitrogen & $4 \mathrm{de}$ & $20.0 \mathrm{bc}$ & $4.7 \mathrm{a}$ & 131.6 & & - & - & - & - & - & - & - \\
\hline & $\begin{array}{l}\text { Legin + Lime- } \\
\text { pellet }\end{array}$ & $13 a b$ & $61.0 \mathrm{a}$ & $3.1 \mathrm{~b}$ & 92.1 & $16 a b c d$ & $112.2 \mathrm{a}$ & $1.9 \mathrm{ab}$ & $62.8 \mathrm{abc}$ & 535abcd & 3 & 2.66 & 4.8 \\
\hline & $\begin{array}{l}\text { Legin }+ \\
\text { [Lime+TSP]-pellet }\end{array}$ & - & - & - & - & $22 \mathrm{ab}$ & 107.7ab & $2.0 \mathrm{ab}$ & 65.6ab & $768 \mathrm{ab}$ & 4.3 & 2.55 & 5.1 \\
\hline \multirow{3}{*}{$\begin{array}{c}7.0 \\
\text { (Broadcast } \\
\text { and } \\
\text { Mixed) }\end{array}$} & $\begin{array}{l}\text { Control (no } \\
\text { inoculation) }\end{array}$ & - & - & - & - & le & $8.3 \mathrm{e}$ & $1.6 \mathrm{abcd}$ & 43.9abcde & $343 \mathrm{cde}$ & 1.9 & 1.53 & 2.9 \\
\hline & Legin & $7 \mathrm{~cd}$ & $20.0 \mathrm{bc}$ & $2.8 \mathrm{~b}$ & 89.9 & $13 \mathrm{~cd}$ & $66.7 \mathrm{~cd}$ & $2.1 \mathrm{ab}$ & $77.8 \mathrm{a}$ & $569 \mathrm{abcd}$ & 3.5 & 3.19 & 6.3 \\
\hline & Nitrogen & 3de & $5.0 \mathrm{c}$ & $5.0 \mathrm{a}$ & 165.8 & & - & - & - & - & - & - & - \\
\hline
\end{tabular}

Values in the same column followed by the same letter at the same column are not significantly different by Multiple Duncan's test at P<0.05 (MSTAT-C, $1988) .{ }^{*} \mathrm{~N}$ total any treatment $-\mathrm{N}$ total zero control $(26 \mathrm{mg} / 18$ plants $){ }^{* *}$ Pyield - Ppellet + seed. $P$ seed $=0.7 \% \%^{* * *} X 50 \mathrm{~kg} \mathrm{seed} \mathrm{ha}^{-1}=0.35 \mathrm{~kg} \mathrm{Pha}^{-1}\left({ }^{* * *}\right.$ Anonymous, 1981). Ppellet $=0.47 \times 10 \mathrm{~kg} \mathrm{TSP} \mathrm{ha}{ }^{-1}=4.7 \mathrm{~kg} \mathrm{P}_{2} \mathrm{O}_{5}=1.35 \mathrm{~kg} \mathrm{Pha}^{-1}$.

However, the application of a high level of lime gave negative effects on nodulation. It was found that the number and weight of nodules were increased with $3.5 \mathrm{tha}^{-1}$ of lime, but decreased when the level of lime was raised to $7.0 \mathrm{tha}^{-1}$. Similar results were found in the pot experiment (Table 4). 
Table 4. Growth and Nodulation of Soybean cv.Tidar at Sitiung Inoculated with B. japonicum with Different Treatments of Lime and Lime-pelleting (Pot Experiment)

\begin{tabular}{|c|c|c|c|c|c|c|c|c|c|}
\hline \multirow{3}{*}{$\left.\operatorname{Lime}_{(\mathrm{t} \mathrm{ha}}^{-1}\right)$} & \multirow{3}{*}{ Inoculation } & \multicolumn{4}{|c|}{ Experiment I } & \multicolumn{4}{|c|}{ Experiment II } \\
\hline & & \multicolumn{2}{|l|}{ Nodule } & \multicolumn{2}{|c|}{ Shoot } & \multicolumn{2}{|c|}{ Nodule } & \multicolumn{2}{|c|}{ Shoot } \\
\hline & & Number plant ${ }^{\prime}$ & Score & $\begin{array}{c}\text { Dry } \\
\text { Weight } \\
\left(\mathrm{g} \text { plant }{ }^{-1}\right)\end{array}$ & $\begin{array}{c}N \text { total } \\
\left(\mathrm{mg}^{\left.-1 a n t^{-1}\right)}\right.\end{array}$ & Number plant ${ }^{-1}$ & $\begin{array}{c}\text { Dry } \\
\text { Weight } \\
\left.\text { (g plant }{ }^{-1}\right)\end{array}$ & $\begin{array}{c}\text { Dry } \\
\text { Weight } \\
\text { (g plant }^{-1} \text { ) }\end{array}$ & $\begin{array}{c}\mathrm{N} \text { total } \\
\text { (mg plant }\end{array}$ \\
\hline \multirow{5}{*}{0.0} & Control (no inoculation) & 0 & 0 & 2.6 & 6.2 & 0.0 & 0.00 & 2.45 & 13 \\
\hline & Legin' & 11 & 2.5 & 2.5 & 7.2 & $\therefore$ & $\therefore$ & - & - \\
\hline & Legin' + Lime-pellet & 11 & 4.5 & 3.8 & 11.3 & 20.0 & 0.03 & 3.15 & 12 \\
\hline & Legin + TSP-pellet & - & & - & - & 2.0 & 0.05 & 2.65 & 11 \\
\hline & Legin + [Lime+TSP]-pellet & - & & - & - & 37.0 & 0.12 & 5.90 & 23 \\
\hline \multirow{5}{*}{$\begin{array}{c}2.0 \\
\text { (Mixed) }\end{array}$} & Control (no inoculation) & - & & - & - & 4.0 & 0.01 & $\mathrm{C}$ & $\mathrm{C}$ \\
\hline & Legin & - & & - & - & 19.0 & 0.03 & 5.35 & 22 \\
\hline & Legin + Lime-pellet & - & & - & - & 30.0 & 0.06 & 5.83 & 23 \\
\hline & Legin + TSP-pellet & - & & - & - & 13.0 & 0.06 & 7.68 & 33 \\
\hline & Legin $+[$ Lime+TSP $]$-pellet & - & & - & - & 54.0 & 0.14 & 7.63 & 30 \\
\hline \multirow{5}{*}{$\begin{array}{c}3.5 \\
\text { (Mixed) }\end{array}$} & Control (no inoculation) & - & & - & - & 2.0 & 0.00 & 5.53 & 35 \\
\hline & Legin & 13 & 4.5 & 4.6 & 14.4 & 15.0 & 0.02 & 6.0 & 30 \\
\hline & Legin + Lime-pellet & 21 & 5.0 & 4.7 & 15.6 & 36.0 & 0.08 & 6.93 & 29 \\
\hline & Legin + TSP-pellet & - & & - & - & 14.0 & 0.02 & 3.93 & 18 \\
\hline & Legin $+[$ Lime + TSP $]$-pellet & - & & - & - & 60.0 & 0.24 & 8.90 & 44 \\
\hline \multirow{2}{*}{$\begin{array}{c}7.0 \\
\text { (Mixed) }\end{array}$} & Control (no inoculation) & 1 & 2.0 & 4.4 & 12.7 & 0.0 & 0.00 & 5.10 & 29 \\
\hline & Legin & 11 & 2.0 & 4.7 & 14.6 & 6.0 & 0.06 & 6.53 & 33 \\
\hline
\end{tabular}

Nodulation score : $0=$ no $\mathrm{N}$ fixed. $5=$ Effective BNF. $\mathrm{C}=$ Contaminated

In the field experiment II (Table 3), application of 2.0 $\mathrm{tha} \mathrm{h}^{-1}$ of lime broadcast and pelleting the soybean seeds with lime at $50 \mathrm{~kg} \mathrm{ha}^{-1}$ and $10 \mathrm{~kg} \mathrm{TSP} \mathrm{ha}^{-1}$ produced $301 \mathrm{~kg} \mathrm{ha}^{-1}$ more yield than from soils with $7.0 \mathrm{t} \mathrm{ha}^{-1}$ of lime. The results of pot experiment II confirm these findings (Table 4).

$\mathrm{N}$-fixation was also increased with lime and pelleting. Without lime, the amount of $\mathrm{N}$-fixed was increased from 12 $\mathrm{mg}$ with lime-pelleting to $24 \mathrm{mg}$ with [lime+TSP]-pelleting. Assuming that there was no $\mathrm{N}$ mineralisation due to liming, the amount of $\mathrm{N}$ fixed by pelleting with lime and TSP of plants grown in the soil with $2.0 \mathrm{tha}^{-1}$ of lime was similar to the amount of $\mathrm{N}$ fixed by the inoculated plants grown in the soils with $7.0 \mathrm{t}$ lime ha ${ }^{-1}$ (Table 3).

$P$ yield was increased by lime and [lime+TSP]pelleting soybean seeds. In this study it was found that liming the soil increased $P$ yield of soybean regardless of seed pelleting treatments (Table 3 ). The highest $P$ yield was obtained from applications of $2.0 \mathrm{t} \mathrm{ha}^{-1}$ of lime broadcast and pelleting the soybean seeds with $50 \mathrm{~kg} \mathrm{ha}^{-1}$ of lime and $10 \mathrm{~kg} \mathrm{ha}^{-1}$ TSP. Similar results were also found on the total $P$ uptake by the plants.

The significance of the adequacy of $P$ in the early stages of soybean growth for establishment and growth and BNF were shown in this study. The responses to the added $P$ for nodulation, growth and yield of soybean were obvious both in field and pot experiments. Plant yield and BNF were greatly increased by the addition of a small amount of $P$ fertiliser with the lime used to pellet the soybean seeds (Table 3). This indicates that $P$ is very essential for the early stage of soybean growth, and the deficiency of $P$ more determinant factor than acidity in the Sitiung soils. It is clearly shown on the results obtained from unlimed soils. Soil $\mathrm{pH}$ close to seedling both on lime-pellet and [lime+TSP]- pellet might not differ (Table 5). Most likely the small amount of $P$ in the seed-pellet was readily exploited by the developing seedlings and fostered root growth. This is in agreement with the results of Hallmark and Barber (1984), and is clearly shown in the result of rhizotron experiment. Root growth of the soybean in soil treated with lime+TSP was much better than in the soils with lime.

The availability of $P$ in the early stage plays an important role in nodulation and BNF of soybean. Nodulation were improved in field, pot and rhizotron experiments. However, the effect was more pronounced on the weight than on the number of nodules, as was also shown by Gates and Muller (1979) and Wan Othman et al. (1991). The effect of $P$ on nodule activity was more likely through the host-plant, although this has been disputed (DeMooy et al., 1973; Singleton, et al., 1985; Israel, 1993). In the rhizotron experiment, it appeared that there was a strong correlation between the development of the root system and nodule activity. There were no differences in the root systems of soybean plants of lime-pelleted or [lime+TSP]-pelleted seeds 7 days after the start of treatments (Waluyo et al., 2004). However, the differences were evident in the plants that were harvested 20 days after the start of treatments. The root systems of plants from [lime+TSP]-pelleted seeds had greater root surface areas per plant and per gram of root than from lime-pelleted seeds.

There was an indication in the rhizotron experiment (Table 5) that $P$ ions also had a direct effect on the Bradyrhizobium infection process. $P$ plays an important 
role in the nodulation process (Israel, 1993), and the infection proces of Bradyrhizobium is transient and takes place at around 12-48 hours after inoculation (Turgeon and Bauer, 1982). Adequate $P$ in the early stages of nodulation may sustain the survival of the Bradyrhizobium on inoculated seeds and support the colonisation of rhizosphere by Bradyrhizobium. It has been reported that low soil P contributes to the poor survival of some rhizobial strains in soils (Beck and Munns, 1984). Colonisation of the rhizosphere and nodule initiation are growth rate dependent (Dart, 1977). Casmann et al. (1981) also found that Rhizobium grown on a P-deficient medium was less effective than Rhizobium from a medium with adequate $P$. The fact that the number of nodules was higher with [limeTSP]-pelleting than with lime-pelleting is in agreement with these reports in the literature. Besides the importance of $\mathrm{P}$, it can be expected that lime in the seed-pelleting will protect the bradyrhizobia by increasing the soil $\mathrm{pH}$ and detoxifying $\mathrm{Al}$ ions in the micro-rhizosphere (Robson and Loneragan, 1970; Danso, 1977; Kang et al., 1977). While $P$ is sufficient, root hairs and lateral root density are increased with lime, which in turn increase the number of potential sites for infection and the number of nodules (Bell and Edward, 1987). Munns (1968) and Lie (1969) have already shown that this process is the most sensitive step of nodulation in a rhizosphere of high acidity and $\mathrm{Al}$ toxicity. Recently Hecht-Buchholz et al. (1990) and Brady et al. (1990) reported that soybean root hairs were deformed by $\mathrm{Al}$ in solution culture. They also assumed that inhibition of emerging root hairs by $\mathrm{Al}$ toxicity causes failure in nodulation of soybean.

The increased $\mathrm{N}$ resulting from $\mathrm{BNF}$ by pelleting the seeds alone, however, was not enough to support good growth and yield of the soybean plants. The plants remained small and the yields were negligible, although the colour was dark green (Fig. 2; Table 3), indicating that this soil was very toxic for soybeans. Besides soil $\mathrm{pH}$, there were other factors limiting growth. Al saturation of the soil was 88 percent and $P$ was less than $5.0 \mathrm{ppm}$ (Table 1), while for optimal growth of soybean Al saturation should not exceed $10-20 \%$, and the critical levels of $P$ is $13.0 \mathrm{ppm}$ (Wade et al., 1988). It has been reported that lime-pelleting legume seeds is only potentially succesful where soil acidity is mild (Cregan et al., 1989). Munns (1986) also suggested that soybean grown on acidic soils may be limited by other factors than nodulation failure. They found that the inoculated plants were well nodulated, green, and high in $\mathrm{N}$ even when growth was severely reduced by the acid soils. The plant symptoms indicated that soybean grown on Sitiung soils were limited by both Al toxicity and $P$ deficiency to the host plant. Therefore, apart from pelleting the seeds, an amount of lime was still required for the production of soybean. It was found that the effects of lime-pelleting soybean seeds on dry matter and $\mathrm{N}$ were negligible in unlimed soils, in contrast to lime pelleting seeds in soils treated with lime (Table 3 ). The yields obtained by pelleting soybean seeds with $50 \mathrm{~kg} \mathrm{ha}^{-1}$ of lime both in soil with $2.0 \mathrm{t} \mathrm{ha}^{-1}$ and $3.5 \mathrm{t} \mathrm{ha}^{-1}$ of lime were comparable to the yield obtained from inoculated seeds in soils limed with $7.0 \mathrm{t} \mathrm{ha}^{-1}$.

Besides lime, the availability of $P$ is essential as well in the Sitiung soils. It is clearly shown by the tremendously increased BNF, growth and yields as results of an addition of a small amount of $P$ in the lime-pellet. It was reported earlier by Sudjadi (1984) that applying $200 \mathrm{~kg} \mathrm{TSP} \mathrm{ha-1}$ increased soybean yield from 200 to $700 \mathrm{~kg} \mathrm{ha}^{-1}$ in unlimed Sitiung soils. It is most likely that $\mathbf{P}$ was more available in limed soils than in unlimed soils. The added lime increased availability of $P$ naturally present in soils and that applied in the form of fertiliser. It was observed (not measured) in our experiment, that an application of $3.5 \mathrm{t} \mathrm{ha}^{-1}$ of lime increased the extent and distribution of the root system. Addition of lime also eliminates the toxicity of Al ions, improve root proliferation, increases interaction between root and soil surface, and thereby enhanced $P$ uptake (Sumner and Farina, 1986; Mengel and Kirkby, 1987). Diatloff and Luck (1972) also found that in acid soils with a high level of exchangeable $\mathrm{Al}$, in addition to seed inoculation, a high rate of lime was required for satisfactory legume growth and $\mathrm{N}$ fixation. However, it is important to note that the excessive use of lime may cause nodulation failure too.

An interesting result was obtained when TSP was used alone as a seed-pellet, without lime. Pelleting the peat-base inoculated seeds with P (TSP) had a harmful effect on the germination (data not presented). This was most probably caused by salt-injury from the TSP fertiliser. It has been reported that the addition of TSP in a band decreased the $\mathrm{pH}$ of the soil surrounding the band by up to 2 units (Forth and Ellis, 1988), and sowing the inoculated seeds in contact with acid superphosphate fertilisers had been found injurious to the bacteria and to germination or the seeds (Diatloff and Luck, 1972).

Table 5. Effects of $\mathrm{CaCO}_{3}$ and $\left[\mathrm{CaCO}_{3}+\mathrm{TSP}\right]$ Applied as Solution on Soil pH, Al, P, Growth of Lateral Root and Nodulation of Soybean Using Sitiung Soil (Rhizotron experiment)

\begin{tabular}{|c|c|c|c|c|c|c|c|}
\hline \multirow[b]{2}{*}{ Treatment } & \multirow[b]{2}{*}{$\begin{array}{l}\text { Soil } \mathrm{pH}^{*} \\
\left(\mathrm{CaCl}_{2}\right)\end{array}$} & \multirow[b]{2}{*}{$\begin{array}{c}\mathrm{Al} \\
\left(\mathrm{mg} \mathrm{L}^{-1}\right)\end{array}$} & \multirow[b]{2}{*}{$\underset{\left(m g ~ L^{-1}\right)}{P}$} & \multirow{2}{*}{$\begin{array}{l}\text { Number of lateral } \\
\text { root } 1^{\text {st }} \text { and } 2^{\text {nd }} \\
\text { order at } 7 \text { days } \\
\text { after treatment }\end{array}$} & \multicolumn{2}{|c|}{ Nodulation plant ${ }^{-1}$} & \multirow{2}{*}{$\begin{array}{c}\text { Fresh Weight } \\
\text { Shoot plant } \\
\text { (g) }\end{array}$} \\
\hline & & & & & Number & $\begin{array}{l}\text { Fresh Weight } \\
\text { (mg nodule }{ }^{-1} \text { ) }\end{array}$ & \\
\hline Control & 4.1 & 9.75 & 0.004 & $50 \mathrm{a} 56 \mathrm{~b}$ & $2.0 \mathrm{c}$ & $1.0 \mathrm{c}$ & $0.426 \mathrm{~b}$ \\
\hline $\mathrm{CaCO}_{3}$ & 7.1 & 0.04 & 0.042 & $43 a 82 a$ & $11.0 \mathrm{~b}$ & $1.5 b$ & $0.790 \mathrm{a}$ \\
\hline $\mathrm{CaCO}_{3}+\mathrm{TSP}$ & 6.8 & 0.05 & 0.044 & $44 a 72 a b$ & $16.0 \mathrm{a}$ & $2.8 \mathrm{a}$ & $0.890 \mathrm{a}$ \\
\hline
\end{tabular}

Values followed by the same letter at the same column are not significantly different by Multiple Duncan's Test at P $<0.05$ (MSTATC. 1988). Extracted with $0.01 \mathrm{M} \mathrm{CaCl}_{2}$ and analysed by Continuous-flow Analysis (Novozamsky et al., 1993; Houba et al., 1994) 
It is clear that cultural practices aimed at alleviating soil constraints to soybean $\mathrm{N}$ fixation and growth in acid soils has to be planned carefully, and must be fine-tuned when attempting to provide soil environments conducive to sustained maximum symbiosis, establishment and growth. $P$ nutrient is a major factor in Sitiung soils. This finding is similar to the previous reports (Sudjadi, 1984; Wade et al., 1988). However the management of $P$ fertilisation is not so simple as reported by Wade (1988). In this study, the availability of $P$ in the early stage is very essential for BNF, growth and yield of soybean. More detailed investigations are essential because it is difficult to distinguish whether the effect of $P$ is on nodulation perse or through the improved host-plant growth.

\section{CONCLUSION}

A combination of a small amount of broadcast lime $\left(2.0 \mathrm{t} \mathrm{ha}^{-1}\right)$ and pelleting soybean seeds with lime $(50 \mathrm{~kg} \mathrm{ha}$ ') and TSP (10 kg TSP ha ${ }^{-1}$ ) was found an appropriate management practice to improve soybean BNF and production on strongly acid soils in Sitiung, West Sumatra.

Application of $P$ is essential to growth and BNF of soybean in strongly acid soils. However, it is interesting to note that the positive effect of $P$ on strongly acid soils is clearly dependent on the way of application. Phosphate must be applied so that the roots can easily reach it.

BNF is a very important natural process in agricultural practices. However, improvement of sustainable agricultural production will need an efficient BNF as a main source of $\mathrm{N}$ for crops. To do so, improved crops, efficient brady- and sinorhizobia, and appropriate management practices must be developed.

A low-input management practice is an appropriate agriculture technique to improve growth and yield of soybean in heavily weathered acid soils. It is not expensive and affordable by poor local farmers, the technique is also very important for the sustainability of agriculture in general. Since Al toxicity and $P$ deficiency are the main problems in heavily acid soils. For the low-input production of soybeans considerations should be directed to the correction of these factors.

\section{ACKNOWLEDGEMENTS}

The author wish to thank to Dr. Ir. Tek An Lie and Prof. Willem M. de Vos Laboratory of Microbiology, Department of Agrotechnology and Food Sciences, Wageningen Uinversity, Hesselink van Suchtelenweg 4, 6703 CT, Wageningen, The Netherlands. Phone: $+31-317$ 483102 / 482105. Fax.: +31-317-483829 and to Prof. Leendert 't Mannetje Department of Plant Sciences, Wageningen University, Haarweg 333, 6709 RZ, Wageningen, The Netherlands. Phone: $+31-317-483045$. Fax.: +31-317-84575 for their valuable supervision, discussion and for revising the manuscript. These study was financed by the Laboratory of Microbiology, Dept. Laboratory of Microbiology, Department of Agrotechnology and Food Sciences, Wageningen
Uinversity, Hesselink van Suchtelenweg 4, 6703 CT, Wageningen, The Netherlands. Phone: $+31-317-483102$ I 482105. Fax. : +31-317-483829.

\section{REFERENCES}

Abruna, F. 1979. Response of soybeans to liming on acid tropical soils. In F.T. Carbin (ed.). World Soybean Research Conference II. West View Boulder, Colorado, United States of America. p. 35-46.

Alva, A.K., D. G. Edwards, C. J. Asher, and S. Suthipradit. 1987. Effects of acid soil infertility factors on growth and nodulation of soybean. Agron. J., 79: 302-306.

Anonymous. 1981. Handbook on phosphate fertilization. ISMA. ISMA Itd. 28 rue Marbent 75008. Paris, France.

Beck, D. P. and D. N. Munns. 1984. Phosphate nutrition of Rhizobium sp. Appl. Environ. Microbiol., 47: 278-282.

Bell, L. C. and D. G. Edwards. 1987. The role of aluminum in acid soil infertility. In M. Latham (ed.). Soil Management Under Humid Conditions in Asia and Pacific. IBSRAM Proceedings No. 5, Bangkok, Thailand. p. 201-223.

Bhuvaneswari, T. V., B. G. Turgeon, and W. D. Bauer. 1980 Early events in the infection of soybean (Glycine max $L$. Merr ) by Rhizobium japonicum. I. Localization of infectible root cells. Plant Physiol., 66: 1027 - 1031.

Borkert, C. M. and S. A. Barber. 1985. Soybean shoot and root growth and phosphorus concentration as affected by phosphorus placement. Soil Sci. Soc. Am. J., 49: 152-155.

Brady, D. J., C. H. Hecht-Buchholz, C. J. Asher, and D. G. Edwards. 1990. Effects of low activities of aluminum on soybean (Glycine max) I. Early growth and nodulation. In M. L. van Beusichem (ed.). Plant Nutrition-Physiology and Applications. Kluwer Academic Press. Dordrecht, The Netherlands. p.329-334.

Brockwell, J, R. R. Gault, D. L. Chase, G. L. Turner, and F. J. Bergersen. 1985. Establishment and expression of soybean symbiosis in a soil previously free of Rhizobium japonicum. Aust. J Agric. Res., 36: 397-409.

Cassman, K .G., D. N. Munn, and D. P. Beck. 1981. Growth of rhizobium strains at low concentration of phosphate. Soil Sci. Soc. Am. J., 45: 520-523.

Coventry, D. R. and J. Evans. 1989. Symbiotic nitrogen fication and soil acidity. In A. D. Robson (ed.). Soil Acidity and Plant Growth.. Academic Press, Australia. p. 103-137.

Cregan, P. D., J. R. Hirth, and M. K. Conyers. 1989. Ametioration of soil acidity by liming and other amendments. In A. D. Robson (eds.). Soil Acidity and Plant Growth. Academic Press, Australia. p. 205-264.

Danso, S. K. A. 1977. The ecology of Rhizobium and recent advances in the study of the ecology of Rhizobium. In A. Ayanaba and P. J. Dart (eds.). Biological nitrogen fixation in farming systems of the tropics. John Willey Sons, Chichester, United Kingdom. p. 115-125.

Dart, P. 1977. Infection and development leguminous nodules. In R. W. F. Hardy and W. S. Silver (eds.). Treatise on dinitrogen fixation. John Wiley and Sons Inc. New York, United States of America. p. 367-472. 
DeMooy, C. J., J. Pesek, and E. Spaldon. 1973. Mineral nutrition. In B. E. Caldwell (ed.). Soybean: Improvement, production and uses. Agronomy 16. ASA. Madison, Wisconsin, United States of America. p. 267-352.

Diatloff, A. and P. E. Luck. 1972. The effects of the interactions between seed inoculation, pelleting and fertilizer on growth and nodulation of Desmodium and Glycine on two soils in S. E. Quensland. Trop. Grass, 6: 33-38.

Foth, H. D. and B. G. Ellis. 1988. Soil Fertility. John Willey \& Son, Inc. United States of America.

Gates, C. T. and W. J. Muller. 1979. Nodule and plant development in the soybean, Glycine max (L.) Merr: Growth response to Nitrogen, Phosphorus and Sulfur. Aust. J. Bot., 27: 203-215.

Hallmark, W. B. and S. A. Barber. 1984. Root growth and morphology, nutrient uptake, and nutrient status of early growth of soybeans as affected by soil P and K. Agron. J., 76: 209-212

Hecht-Buchholz Ch., D. J. Brady, C. J. Asher, and D. G. Edwards. 1990. Effect of low activities of aluminium on soybean II. Root structure and root hair development. In M. L. Van Beusichem (ed.). Plant Nutrition-Physiology and Application. Kluwer Academic Publishers, Dordrecht, The Netherlands. p. 335-343.

Houba, V. J. G., I. Novozamsky and E. Temmimnghoff. 1994. Soil analysis procedures Extraction with $0.01 \mathrm{M} \mathrm{CaCl}_{2}$ (Soil and Plant Analysis, Part 5A).

Kang, B. T., D. Nangju, and A. Ayanaba. 1977. Effect of fertilizer use on cowpea and soybean nodulation and nitrogen fixation in the low land tropics. In A. Ayanaba and P. J. Dart (eds.). Farming Systems of the Humic Tropics. John Wiley \& Sons, Chichester, United Kingdom. p. 205-216.

Israel, D. W. 1993. Symbiotic dinitrogen fixation and host-plant growth during development of and recovery from phosphorus deficiency. Physiol. Plant, 88: 294-300.

Lie, T. A. 1969. The effect of low pH on different phases of nodule formation in pea plants. Plant Soil 31: 391 -405.

Mannetje, L. t. 1967. Pasture improvement in the estate district of South Eastern Queensland. Trop. Grassl., 1: 9-19.

Mengel, K. and E. A. Kirkby. 1987. Principles of plant nutrition. International Potash Institute, Switzerland.

MSTAT.C. 1988. A Software program for the Design, Management, and Analysis of Agronomic Research Experiments. Michigan State University, United States of America.

Munns, D. N. 1968. Nodulation of Medicago sativa in solution culture. I. Acid-sensitive steps. Plant Soil, 28: 129-146.

Munns, D. N. 1977. Soil acidity and related factors. In J. M .Vincent, A. S. Whitney and J. Bose (eds.). Exploiting the
Legume-Rhizobium Symbiosis in Tropical Agriculture. College of Tropical Agriculture Miscellaneous Publication 145. Department of Agronomy and Soil Science, University of Hawaii, United States of America. p. 211-236.

Munns, D. N. 1986. Acid soil tolerance in legumes and thizobia. In B. Tinker and A. Lauchli. (eds.). Adtances in Plant Nutrition Vol. 2. Praeger, New York, United States of America. p. 63-91.

Novozamsky, I., D. van Dijk, J. J. van der Loe, and V. J. G. Houba. 1993. Automated determination of trace amounts of phosphate in soil extracts using malachite green. Commun. Soil Sci. Plant Anal., 24 (9 and 10): 1065-1076.

Robson, A. D. and J. F. Loneragan. 1970. Nodulation and growth of Medicago truncatula on acid soils 1 . Effect of calcium carbonate and inoculation level on the nodulation of Medicago truncatula on a moderately acid soils. Aust. $J$. Agric., Res. 21: 427-434.

Sanchez, P. A. and J. G. Salinas. 1981. Low input technology for managing Oxisols and Ultisols in tropical America. Adv. Agron., 34: 280-400.

Sartain, J. B. and E. J. Kamprath. 1975. Effect of liming a highly aluminum saturated soil on the top and root growth and soybean nodulation. Agron. J., 67: 507-510.

Singleton, P. W., H. M. Abdel Magid, and J. W. Taveres. 1985. Effect of phosphorus on the effectiveness of strains of Rhizobium japonicum. Soil Sci. Soc. Am. J., 49: 613-616.

Sudjadi, M. 1984. Problem soils in Indonesia and their management. In Ecology and Management of Problem Soils in Asia. FFTC Book Series No. 27, Taiwan, Rep. of China. p. 48-73.

Summer, M. E. and M. P. W. Farina. 1986. Phosphonus interactions with other nutrients and lime in field cropping systems. Adv. Soil Sci., 5: 201-236.

Turgeon, B. G. and W. D. Bauer. 1982. Earty events in the infection of soybean Rhizobium japonicum. Time course and cytology of the initial process. Can. J. Bot. 60: 152-161.

Wade, M. K., D. W. Gill, H. Subagjo, M. Sudjadi, and P. A. Sanchez. 1988. Overcoming soil fertility constraints in a transmigration area of Indonesia. Trop Soil Bulletin Number 88-01. North Carolina State University, Raleigh, NC 27697113, United States of America.

Waluyo, S. H., T. A. Lie, W. M. de Vos, and, L.'t. Mmnetje. 2004. Effect of Phosphate on Nodule primordia of Soybean (Glycine max Merrill) in Acid Soils in Rhizotron Experimerts. Indonesian J. Agric. Sci., 5(2): 37 - 44.

Wan Othman, W. M., T. A. Lie, L. t Mannetje, and G. Y. Wassink. 1991. Low level phosphorus supply affocting nodulation, $\mathrm{N}_{2}$ fixation and growth of coupea (Vigna unguiculata L. Walp). Plant Soil, 135: 67-74. 